\title{
Rocznik Andragogiczny 2012, Wyd. ITE, Warszawa-Toruń 2012
}

Rocznik Andragogiczny 2012 składa się z ośmiu działów: W oczekiwaniu na II Zjazd Andragogiczny, 2012 - Międzynarodowy Rok Edukacji Międzypokoleniowej, Analizy i badania edukacji dorosłych, Raporty z projektów badawczych, Aktualia, Sprawozdania z konferencji, Zaproszenia na konferencje oraz Recenzje. XIX tom publikacji zamyka Felieton o Roku 2012 autorstwa Józefa Półturzyckiego.

Pierwszy dział - Woczekiwaniu na II Zjazd Andragogiczny to zbiór trzech artykułów. Edukacja dorosłych jako działalność społeczno-oświatowa, traktuje o istocie edukacji dorosłych, jej rozwoju oraz wartości dla jednostki i społeczeństwa. Autor analizuje pojęcie oświaty dorosłych, przywołując liczne definicje oraz wyjaśnia jak to pojęcie ewoluowało na przestrzeni lat. Autor dostrzega wartości płynące $\mathrm{z}$ działalności pozarządowych programów edukacji dorosłych, wkładu środowisk społecznych oraz rodzinnych form edukacji międzypokoleniowej. Agnieszka Stopińska-Pająk powraca do źródła i w swoim artykule, pisze o ukazaniu się przed 100 laty pierwszego podręcznika edukacji dorosłych Praca oświatowa. Jej zadania, metody, organizacja. Podręcznik opracowany staraniem Uniwersytetu Ludowego im. A. Mickiewicza. Ewa Skibińska z kolei zwraca uwagę na jeszcze jedno ważne w dziejach polskiej myśli andragogicznej wydarzenie - 20-letnią działalność Akademickiego Towarzystwa Andragogicznego. Towarzystwo zostało zarejestrowane 31 grudnia 1993 roku w Warszawie, a rok później ukazał się pierwszy tom Rocznika Andragogicznego. Dzięki współpracy z wieloma instytucjami, zarówno w kraju, jak i zagranicą możliwe jest poszerzanie kierunków i form działania Towarzystwa oraz poszukiwanie sposobów wspierania rozwoju człowieka ułatwiając mu realizację indywidualnego planu życiowego. 
Na drugi dział składają się cztery artykuły związane z Międzynarodowym Rokiem Edukacji Międzypokoleniowej. Ludmiła Zając-Lamparska pisze o pomyślnym starzeniu się oraz dokonuje przeglądu i analizy porównawczej koncepcji psychologicznych dotyczących tego zjawiska. Omawia teorię aktywności, wyłączenia, ciągłości i dowodzi tym samym, jak styl życia wpływa na realizację człowieka. Alicja Kozubska i Przemysław Ziółkowski skupiają się na Potrzebie sensu życia jako czynniku spajajacym pokolenia. Przekonują, że postawa człowieka ma charakter dynamiczny i zależy od okresu rozwojowego, w którym się on znajduje. $Z$ pojęciem sensu nierozerwalnie wiążą się wartości przekazywane w procesie wychowania. W związku z tym, że w okresie dorastania i starzenia się człowiek jest najbardziej narażony na kryzys wartości, zwraca się uwagę na wzajemną współpracę wyżej wymienionych pokoleń. Dział zamykają artykuły Piotra Błajeta oraz Beaty Stachowiak, traktujące o aktywności prozdrowotnej seniorów oraz ich udziale w społeczeństwie informacyjnym. Piotr Błajet przedstawia Aktywną Strategię Umacniania Zdrowia (ASUZ) oraz pięcioczynnikowy program aktywności obejmujący personalizację, integralność, wyzwania, kooperację i osobiste cele, odpowiadający ośmiu fazom rozwoju E. Eriksona i kryzysom, które ma do pokonania człowiek na drodze swojego rozwoju.

Dział trzeci recenzowanej pozycji składa się z trzech podrozdziałów. Pierwszy, Teoretyczne Podstawy, rozpoczyna artykuł Anny Frąckowiak, która zajmuje się Zmianq jako kategoriq edukacji dorosłych. Pojęcie zmiany odgrywa istotną rolę na każdym etapie życia jednostki. We współczesnym społeczeństwie, którego jedyną cechą stałą jest zmienność musi nauczyć się żyć człowiek dojrzały, starzejący się. A. Frąckowiak przekonuje, że ta nauka nie musi być trudna, czy uciążliwa. Wyzwaniem jest kształtowanie twórczych postaw wobec zmian oraz podejścia, że każda z nich może stać się okazją do zdobycia nowych doświadczeń. W artykule Renaty Góralskiej przeczytać możemy o kompetencjach emocjonalnych, które z uwagi na swój nietechniczny charakter i połączenie $\mathrm{z}$ refleksją są pomijane $\mathrm{w}$ racjonalnie i technokratycznie zdominowanej edukacji. Kompetencje te pomagają człowiekowi radzić sobie w różnych sytuacjach, jednocześnie są warunkiem twórczego i aktywnego uczestnictwa w zmieniającym się społeczeństwie.

Monika Staszewicz i Katarzyna Jurzysta poruszyły temat innowacyjności i jej iznaczenia dla całożyciowego uczenia się. W swoim artykule autorki poruszyły problem zatrudnienia pracowników, którzy nie spełniają wymagań stawianych przez pracodawców, mimo posiadanego wyższego wykształcenia. Omówiły też priorytety wyznaczone przez Unię Europejską w zakresie uczenia się dorosłych. Poprawa jakości i skuteczności kształce- 
nia i szkolenia, promowanie równości, zwiększanie kreatywności oraz ulepszanie otoczenia edukacyjnego to tylko niektóre z nich. Violetta Kopińska przygląda się Edukacji prawnej z perspektywy humanistyczno-krytycznej. Wyjaśniając pojęcie edukacji prawnej przekonuje, że powinna stać się ona przedmiotem zainteresowania każdego człowieka, bowiem dotyczy go na różnych etapach życia. Jest to całożyciowe doświadczenie, ponieważ jesteśmy adresatami zmieniających się regulacji prawnych, jako osoby pełniące wiele różnych ról społecznych. Celem prawidłowo realizowanej edukacji prawnej jest wykształcenie ludzi świadomych oraz przestrzegających praw i obowiązków oraz zdolnych do kreowania swej tożsamości oraz odrębności.

Michał Szykut omawia Elementy szacowania ryzyka w pracy kuratorów dla dorostych $w$ Polsce. Swój artykuł poświęcił rozważaniom nad jednym $\mathrm{z}$ wielu obowiązków kuratora sądowego, jakim jest wykonywanie dozorów.

W rozdziale drugim zatytułowanym $Z$ historii oświaty dorostych przeczytamy artykuł o Filozoficznych podstawach kształcenia $w$ przedwojennym Wrocławskim Uniwersytecie Powszechnym autorstwa Iwony Alechnowicz-Skrzypek. Autorka pisze o powstaniu Uniwersytetu i początkach jego działalności. Głównym celem, jaki postawili sobie profesorowie było upowszechnienie wiedzy i kształcenie dorosłych, pracujących osób, rzemieślników. Klasa robotnicza miała nauczyć się samodzielnie myśleć, odkryć swoje powołanie i uczestniczyć w kulturze wyższej. Wszechstronny rozwój osobowości jest możliwy tylko wtedy, gdy człowiek prowadzi wartościowe życie. Takiego życia uczył Wrocławski Uniwersytet Powszechny. Na problemach szkolnictwa przywięziennego na łamach „Oświaty Dorosłych” (1957-1990) skupia się Eleonora Sapia-Drewniak. Kolejne publikacje przybliżają osoby: Franciszka Urbańczyka - dydaktyka dorosłych, Haliny Semenowicz - popularyzatorki technik Freineta w świetle jej dzienników oraz Narcyza Kozłowskiego (1913-2000) - pomorskiego społecznika i oświatowca.

Rozdział trzeci poświęcony jest Edukacji dorosłych za granicą. Ewa Kula i Marzena Pękowska porównują Rolę szkolnictwa wyższego w rozwoju kształcenia ustawicznego w Europie i w Polsce. Natalia J. Olechnowicz pisze o Rozwoju podejścia etycznego i kompetencyjnego $w$ kształceniu urzędników na przykładzie rosyjskiej akademii Gospodarki Narodowej i Stużby Państwowej. Obszerny artykuł Piotra Koniecznego przybliża nam powstanie, strukturę i organizację oraz działalność Narodowego Uniwersytetu Kształcenia na Odległość (UNED) w Hiszpanii, który utworzony został w 1972 roku. Rozdział kończy anglojęzyczna publikacja Beaty Pietkiewicz-Pareek, która pokazuje w jaki sposób można wykorzystać edukację dla promowania równości ptci i wzmacniania pozycji kobiet $w$ Indiach. 
Następny dział zawiera pięć Raportów z projektów badawczych. Anna Matusiak i Hanna Solarczyk zajęły się Bilansem kapitału ludzkiego w Polsce w latach 2010-2012. W artykule przeczytamy, jakie kompetencje niezbędne są na rynku pracy, jakich kompetencji u pracowników poszukują pracodawcy oraz jak oceniają swoje kompetencje różne grupy społeczne. Autorki formułują wnioski istotne dla edukacji dorosłych i rynku pracy.

W kolejnych raportach przeczytać możemy o pomijaniu kwestii edukacji dorosłych w polityce oświatowej na poziomie lokalnym (Beata Cyboran), kształceniu kadr w trzecim sektorze - organizacjach pozarządowych (Beata Nosek, Łukasz Hajduk), a także o obszarach wykorzystywania potencjału seniorów (Małgorzata Malec, Tomasz Siemież) i przeciwdziałaniu wykluczeniu cyfrowemu osób dorosłych (Dominika Hofman, Łukasz Tomczyk).

W Aktualiach znajduje się nota poświęcona pamięci zmarłego ks. prof. Janusza Tarnowskiego (1919-2012) - twórcy chrześcijańskiej pedagogiki egzystencjalnej. Nie brakuje również informacji o awansach naukowych. Tytuł doktora nauk humanistycznych w zakresie pedagogiki otrzymała Anna Gutowska-Ciołek za pracę pt. Uczenie się dorosłych $w$ sytuacjach przyjaźni perspektywa andragogiczna. W 2013 roku odbyła się również habilitacja dr Anny Frąckowiak, która przedstawiła rozprawę pt. Kształcenie ustawiczne i szkoły wyższe - niedostrzegany potencjał.

Piąty dział Rocznika to zbiór sprawozdań z konferencji, kongresów i sympozjów, które odbyły się w 2012 roku. Autorzy w wyczerpujący sposób zdali relację z tych ważnych dla edukacji dorosłych spotkań, będących okazją do poszerzenia i pogłębienia wiedzy na tematy związane z szeroko pojętą edukacją dorosłych.

Część szósta zawiera Zaproszenia na II Zjazd Andragogiczny w Toruniu oraz XV Letnią Szkołę Andragogów i Poradoznawców w Międzygórzu.

Ostatni dział Rocznika składa się z 18 recenzji, przybliżających czytelnikowi publikacje andragogiczne, które zostały wydane w 2012 roku. Wśród recenzowanych pozycji z dziedziny badań biograficznych w Roczniku znalazło się dzieło jednego z nestorów polskiej historii XX wieku - Mariana Marka Drozdowskiego Juliusz Poniatowski. Zarys biografii oraz Stefania Mazurek. Biografia pedagogiczna autorstwa Eleonory Sapia-Drewniak. Tematykę kompetencji i ich znaczenie w rozwoju zawodowym człowieka, poruszają z kolei publikacje Tomasza P. Czapli Modelowanie kompetencji pracowniczych organizacjach, Renaty Góralskiej i Joanny Madalińkiej-Michalak Kompetencje emocjonalne nauczycieli oraz Elżbiety Lisowskiej Rozpoznawanie i przewidywanie wypalenia zawodowego nauczycieli. Studium pedagogiczne. Problematykę kształcenia ustawicznego zarówno w sferze psychicznej, jak i fizycz- 
nej podejmują autorzy z Polski i Niemiec, w publikacji pod redakcją Elżbieta Dubas i Marianne Friese Learning in Life Stream. The selected Aspects of Andragogy and Vocational Pedagogy in a German and Polish Perspective, Anna Frąckowiak w Ksztatcenie ustawiczne i szkoły wyższe - niedostrzegany potencjał, Ewa Kurantowicz i Adrianna Nizińska w Trajektorie uczenia się w instytucjach kształcenia ustawicznego, Tomasz Maliszewski w Edukacja dorostych wobec społecznego wykluczenia: przeszłość i teraźniejszość oraz Janusz Mucha i Łukasz Krzyżowski w Ku socjologii starości. Starzenie się w biegu życia jednostki i w końcu, studium antopologiczne Piotra Błajeta Od edukacji sportowej do olimpijskiej. W tym dziale znajdujemy też recenzję Dyskursów Młodych Andragogów wydanych pod redakcją Małgorzaty Olejarz. Opieka u kresu życia to przedmiot reflksji Piotra Krakowiaka, którą prezentuje książkach: Społeczne i edukacyjne funkcje opieki paliatywno-hospicyjnej. Badania w działaniu w latach 2002-2010 oraz Wolontariat w opiece u kresu życia. Geneza, rozwój, funkcjonowanie, możliwości integracji i optymalizacji. Ku syntezie socjopedagogicznej. Odrębną grupę stanowi związany z andragogiką regionalizm, którego najwyższą formą jest opracowywanie i wydawanie encyklopedii poszczególnych miejscowości. Jej doskonałym przykładem jest Encyklopedia Gdańska, o której pisze Tadeusz Aleksander. Ostatnie trzy recenzje to periodyki, wśród których znalazły się Rosyjski rocznik edukacji dorosłych - tom 10, Rocznik Andragogiczny 2011.

Ostatnie strony recenzowanej pozycji naukowej zapełnił redaktor naczelny Józef Półturzycki swoim Felietonem. Poświęcił go niezwykłym osobowościom, takim jak B. Prus, J. I. Kraszewski, Z. Krasiński, P. Skarga i wreszcie J. J. Rousseau. 1712, 1812, 1912,(...), autor tradycyjnie w interesujący sposób przedstawił wydarzenia przypadające na lata będące wielokrotnością roku 2012.

Rocznik Andragogiczny 2012 to wartościowa publikacja. Po raz 19. Akademickie Towarzystwo Andragogiczne zaprezentowało w swoim periodyku przyczynki do teorii andragogicznej, praktyki oświatowej, wydarzenia dotyczące edukacji dorosłych oraz recenzje prac z tego obszaru.

Agnieszka Biedzińska, Agata Chorościn 